\title{
Mohannad ALOBID,
} Szűcs ISTVÁN

Faculty of Economic and Business, University of Debrecen, Hungary

Muhamad ZEED

Faculty of Agriculture, University of Alfurat,Syria

\section{THE SOCIAL AND ECONOMIC IMPACT OF SMALL PROJECTS IN AL- HASAKA PROVINCE, SYRIA}

\author{
Keywords \\ Socio-economic Impacts; \\ Beneficiaries; \\ Rural Development Project \\ JEL Classification \\ A13, A20, Q13
}

\begin{abstract}
The study highlights the socio-economic impact of the rural development projects that were carried out in the North-Eastern region of Syria among the local population. This analysis aims to evaluate several aspects: the personal characteristics of the beneficiaries; the activities created by the rural development project; the constraints faced by the beneficiaries, which limited their activities and profit within the rural development project, and their solutions to these limitations. The survey found that $43.3 \%$ of the beneficiary respondents are middle-aged, $47 \%$ can read and write and $35.3 \%$ have an educational qualification. Furthermore, 43.5\% of beneficiaries are medium land holders and $62.8 \%$ own the land they cultivate themselves. Regarding the development training, $44.7 \%$ of beneficiaries attended development training, while $48.2 \%$ received vocational training. $76.5 \%$ of the projects are ongoing, and $98.8 \%$ of the evaluation of the respondents' project was successful. Concerning marketing the mushroom production, $78.3 \%$ had difficulties with marketing their production and 90.5\% suggested help was needed with marketing mushrooms.
\end{abstract}




\section{INTRODUCTION}

Agriculture plays an increasing and critical role in the futures of many developing countries. This may be because agriculture can contribute directly and/or indirectly to economic growth. No one can deny the contribution agriculture has in providing the country's food supply, its role as a valuable source of income for many people as well as a source of raw materials for many manufacturing industries (Adelman \& Morris, 1973; FAO, 2002; Koning, 2017).

Syria is an agricultural country where agriculture has played an important role since ancient times; indeed, it is believed to be the original home of grain crops; agriculture has contributed to the other economic sectors, to the national income, gross domestic product and labour shares. It also contributes to exports, amounting to approximately $15 \%$ of the value of total exports in 2007 (Central Bureau of Statistics, 2007).

Agricultural extension focuses on farmer education by applying scientific research and new knowledge to agricultural practices. Thus it transfers agricultural research results to farmers, and conveys the problems that farmers face in order to find solutions. The extension philosophy is based on educational processes aimed at educating farmers and developing their knowledge, skills, and attitudes in order to make decisions that help them to manage their farms as optimally as they can (Ramirez, 1997).

Extension organizations improve the flow of technology and operate in an institutional environment that includes other organizations associated with the generation and transfer of agricultural technology, including research, education and training, ensuring inputs, finance or loans, farmer associations and other nongovernmental organizations (Rivera \& Qamar, 2003; Swanson, 2005).

Since rural development aims to reduce poverty, it must be clearly designed to increase agricultural sectoral production and raise productivity for all sectors in general. The focus of planners and politicians on rural development is due to several factors, the most important of which are the average populations of rural areas, the low living standards in rural areas, rural poverty, the conflict between development projects, and the fact that the economy of the developing countries is mainly agricultural, thus increasing the development gap (Dixon, Gibbon, Gulliver, \& Hall, 2001; Naseem, Spielman, \& Omamo, 2010).

The economic and social analysis of the progress many countries made indicates that "some Asian countries have made tremendous achievements for the past two decades and transformed from consumer forces to creative productive forces by resorting to small enterprises and industries" (FAO, 2017; Müller-Armack, 1989).

Small projects have become one of the most important elements of economic development and development strategies in most countries. "The flexible nature of these projects is more suited to the new global situation, which requires a rapid response to market demands and the progress of supply and demand; there are more opportunities for these small business than for larger ones which have little flexibility to face market fluctuations (Abdullah, 2020; Agwu \& Emeti, 2014).

The objectives of this research are:

1. To identify the personal characteristics of the target population involved in the activities of the Rural Development Project;

2. To identify the activities provided by the Rural Development Project;

3. To identify the economic and social impacts of the project's activities on the targets;

4. To identify the difficulties facing the beneficiaries in profiting from the activities of the Rural Development Project;

5. To identify propositions aimed at solving the problems facing the beneficiaries.

\section{METHODOLOGY}

This study targets the community of beneficiaries of the programs and activities of the development project in the province of Al-Hasaka, where there are a number of small productive projects (85) funded by the Rural Development Project. All of the production projects have been studied, due to the decreasing number of productive projects in that region. Based on the objectives of the study, a questionnaire was prepared which was administered by the interviewer. The final data for the study were collected from February 18 to April 29, 2018. Eighty-five questionnaires were collected by field interviews on the farmers' fields. The data was analysed using SPSS 15.

\section{RESULTS AND DISCUSSION}

Identification of the personal characteristics of the intended beneficiaries of the activities of the Rural Development Project in Al-Hasaka Governorate (administrative division)

A range of personal and social characteristics of the beneficiaries of the rural development project programme were studied and included the following: age, educational level, marital status, size of tenure, nature of tenure.

\section{Age}

The respondents are divided according to their age into three categories: young people (up to 29 years), 
middle-aged (29 to 44 years), and old people (45 years and over). Approximately half of the respondents $(43.3 \%)$ are middle-aged and old people and a declining percentage of young respondents was noticed: $13 \%$ (Figure 1). This low proportion of young people may indicate that they prefer to find a job in other economic sectors.

\section{Educational level}

The respondents are divided, depending on their educational level, into three categories: illiterate, literate, and those with academic qualifications. Approximately half of the respondents $47 \%$ can read and write, $35.3 \%$ have an academic qualification, and $17.6 \%$ are illiterate (Figure 2). This is may be due to the fact that those studying are better suited to enrol in the Rural Development Project programs because these programs spread innovation and create new jobs based on the initial possibilities.

\section{Marital status}

The respondents are divided by marital status into three groups: single, married, and widowed. It has been noted that the majority of respondents $85.9 \%$ are married, and that single people and widow(er)s make up $3.5 \%$ and $10.6 \%$ of the respondents, respectively (Figure 3), which may indicate that most of the respondents live in families, which leads them to make greater efforts to increase their incomes and improve their living conditions.

\section{Size of tenure}

Respondents with farmland are divided into three groups according to the size of tenure: smallholders (less than 20 dunams), medium holders (from 21 to 50 dunams that is 2.1 to 5 Hectares), large-holders (over 50 dunams), and landless holders. Fewer than half of the respondents are medium holders $43.5 \%$, and approximately one quarter have a large holding $23.5 \%$ (Figure 4 ). The percentage of respondents with a small tenure is $20 \%$, while $13 \%$ have a landless tenure. This may be because the Rural Development Project targets small and mediumsized smallholders, as well as those who do not have their own land.

\section{Nature of tenure}

The respondents were divided according to the nature of tenure they cultivate, into categories: owners, tenants, and those with a landless tenure. It was observed that two-thirds of respondents $62.8 \%$ own the cultivated land and tenants make up $18.8 \%$ (Figure 5).

\section{Identification of activities provided by the Rural Development project in Al-Hasaka Governorate The rural development project in Al-Hasaka Governorate has carried out many activities in the villages targeted by its programs, and the activities have addressed several areas, including the capacity}

of the local community and activating its role in managing the sustainable development process, empowering rural women economically and socially, and training them in various literacy and life skills courses. Young people and unemployed women have acquired diversified incomegenerating skills, environmental awareness campaigns have been implemented, field days have been organised to raise agricultural productivity, modern technologies have been applied, and small enterprises developed. The study aimed at identifying the activities of the Rural Development project in Al-Hasaka governorate, addressing the target individuals whose production projects had been implemented. This information included:

a) Areas of activity provided by the Rural Development Project,

b) Type of training courses offered to respondents,

c) Duration of the project,

d) Type of production projects,

e) Sources of information about the project.

\section{Areas of activity provided by the Rural}

Development Project

Table 1 shows the distribution of respondents according to the areas of activity provided by the Rural Development Project, the respondents' answers and the computation and percentages of the responses. The data from the table shows that the most frequent activities are field visits meant to raise agricultural productivity: $48.2 \%$, followed by health awareness campaigns: $21.1 \%$, followed by awareness campaigns in the area of community development and capacity building: 18.8\%. The least frequent activities were awareness campaigns in the environmental field: $12.9 \%$. This indicates that the more general the topics, the nature and characteristics of activities in rural society are, the more prevalent they are in the activities of the Rural Development Project.

2. The type of the training courses provided for the respondents

Table 2 shows the distribution of respondents according to the type of training courses which respondents do, the respondents' answers, and the calculation of the percentages of these responses. The table data shows that the most typical activities were vocational training (sewing, haircutting, mechanics, 48.2\%), followed by development courses (literacy-first aid, 44.7\%).

3. Duration of project since initiation

Table 3 shows the distribution of respondents according to the period that has elapsed since the start of the project. Thus $69.4 \%$ of respondents started their production projects less than 3 years before, $23.5 \%$ of respondents started working 3-4 years before, and $7.1 \%$ of respondents had been working for more than 4 years; this indicates that 
during the first period of the development projects, the number of productive projects was small, as at that time the project focused on studying the targeted villages and that the number of villages targeted in the early stages was few, while in recent years the number of productive projects increased.

4. The type of production projects

Table 4 shows the distribution of respondents according to the type of production projects while respondents were divided into five categories according to the type of their project. Biogas projects account for $50.6 \%$, solar cooker projects for $21.2 \%$, agricultural mushroom production projects for $18.8 \%$, with modern irrigation projects accounting for $5.9 \%$, and egg incubator projects for $3.5 \%$.

5. Sources of information on the project

We managed to obtain answers from $100 \%$ of the respondents. The information on their productive projects was obtained through Rural Development Project courses. This suggests that the Rural Development Project contributes to the dissemination of innovations and trains respondents.

Identification of the economic and social impacts of the project activities on the targeted individuals in the Al-Hasaka governorate.

This subchapter aims at:

- Identifying the Project Objective

- Investigating the project continuity.

- Evaluating the project from the point of view of the beneficiaries.

- Investigating the economic and social impact of the project.

\section{Identifying the Project Objective}

Table 5 shows the distribution of respondents according to the objective of the project. From the respondents' answers, it appears that for $78 \%$ the aim of the project was to provide an alternative source of household gas and to spread the idea of using clean energy. For $22.4 \%$, the aim was to provide a new source of income, while for $5.9 \%$ it was to spread ideas about developing modern irrigation, drip irrigation, and surface irrigation mechanisms. The Rural Development Project seeks to spread innovations through the productive projects it finances.

2. Investigating the project continuity

It is noted that the majority of the production projects are ongoing $76.5 \%$ and $23.5 \%$ of the projects stalled (Figure 6).

3. Evaluating the project from the point of view of the beneficiaries

$98.8 \%$ evaluated their project as successful, while $1.2 \%$ considered it acceptable (Figure 7); the reasons for the success of productive projects were the follow-up, supervision, financing, and the training provided by the Rural Development Project.

4. Investigating the economic and social impacts of the project

Table 6 shows the distribution of respondents according to the economic and social effects of the project. It is noted that the project generated a new source of income for all respondents.

We note that none of the respondents could purchase electrical appliances through the returns from the project because of the higher prices for electrical appliances and because the returns from the project were not enough to purchase any of these appliances. Most respondents $(96.5 \%)$ were unable to save any money from the returns of the projects, although $3.5 \%$ of respondents were able to save some of the project's income. The reason why most productive projects were beneficial may be that they provided services; they had no material value but a physical impact by reducing spending on other things participants needed. Two-thirds of respondents $(70.6 \%)$ said that the return on their project did not contribute to improving the quality of food, while $29.4 \%$ said it did. All respondents $(100 \%)$ said that the returns did not contribute to their children's school enrolment. We note that for most respondents $(97.6 \%)$ their project did not contribute to any improvement in housing, while $2.4 \%$ stated it did.

Identifying the obstacles facing the target individuals in attempting to benefit from the activities of the Rural Development Project in AlHasaka Governorate

Table 7 shows the distribution of respondents according to the existence of obstacles which faced them, with $27.1 \%$ of the respondents facing obstacles and $72.9 \%$ not.

It is noted that the most frequent impediments faced by respondents were the difficulty of marketing the production of mushrooms, which was mentioned by $78.3 \%$. This may be because the respondents did not have any knowledge about marketing mushrooms, or because of a lack of mushroom markets close to them. The second most typical difficulty was in securing raw materials for the fermenter (13\%) followed by lack of eggs vaccinated in the hatcheries $8.7 \%$ (Figure 8 ).

Identifying the suggestions of the targeted individuals in al-Hasaka governorate to solve the problems they face.

Table 8 shows the distribution of respondents according to the existence of suggestions to solve the problems they faced. $24.7 \%$ of the respondents hadsuggestions to solve their problems while $75.3 \%$ did not. 
The most frequent proposition of respondents was the assistance of the Rural Development Project in marketing mushrooms, which was mentioned by $90.5 \%$, followed by assistance in ensuring a source of vaccinated eggs $9.5 \%$ (Figure 9 ).

\section{CONCLUSIONS}

The rural Development Project contributes to the development and capacity-building of rural society. The Rural Development Project seeks to build productive projects to spread innovations.

Respondents rely on Rural Development Project courses to manage their projects.

Respondents seek to increase their income sources through their projects.

The rural Development Project highlighted:

-the success of productive projects extends over long periods of time the projects finish;

-the respondents' satisfaction with their projects;

-the success of small enterprises in generating new sources of income.

\section{REFERENCES}

[1] Abdullah, M. A. (2020). Small and medium enterprises in Malaysia: Policy issues and challenges: Routledge.

[2] Adelman, I., \& Morris, C. T. (1973). Economic growth and social equity in developing countries: Stanford University Press.

[3] Agwu, M. O. \& Emeti, C. I. (2014). Issues, challenges and prospects of small and medium scale enterprises (SMEs) in Port-Harcourt city. European Journal of Sustainable Development, 3(1), 101-114.

[4] Central Bureau of Statistics (2007). A. S. G., Damascus.
[5] Dixon, J. A., Gibbon, D. P., Gulliver, A., \& Hall, M. (2001). Farming systems and poverty: improving farmers' livelihoods in a changing world: Food \& Agriculture Org.

[6] FAO (The Food and Agriculture Organization) (2017). The future of food and agricultureTrends and challenges: FAO Rome.

[7] FAO (The Food and Agriculture Organization) (2002). The Role Of Agriculture In The Development Of Least-Developed Countries And Their Integration Into The World Economy.

[8] Koning, N. (2017). Food security, agricultural policies and economic growth. Long-term dynamics in the past, present and future. London.

[9] Müller-Armack, A. (1989). The meaning of the social market economy Germany's Social Market Economy: Origins and Evolution (pp. 82-86): Springer.

[10] Naseem, A., Spielman, D. J., \& Omamo, S. W. (2010). Private-sector investment in R\&D: a review of policy options to promote its growth in developing-country agriculture. Agribusiness, 26(1), 143-173.

[11] Ramirez, R. (1997). Understanding farmers' communication networks: combining PRA with agricultural knowledge systems analysis. Paper presented at the Gatekeeper Series No. SA66. London: IIED.

[12] Rivera, W. M., \& Qamar, M. K. (2003). Agricultural extension, rural development and the food security challenge: Food and Agriculture Organization of the United Nations Rome.

[13] Swanson, B. (2005). Improving agricultural extension: Daya Books. 


\section{TABLES \& FIGURES}

Table No 1

Distribution of respondents according to the areas of activity provided by the Rural Development Project

\begin{tabular}{ccc}
\hline Activities & Frequency $\mathbf{n = 8 5}$ & Percentage \% \\
\hline $\begin{array}{c}\text { Awareness campaigns in } \\
\text { the health domain }\end{array}$ & 18 & 21.1 \\
$\begin{array}{c}\text { Awareness campaigns in } \\
\text { the environmental domain }\end{array}$ & 11 & 12.9 \\
$\begin{array}{c}\text { Awareness campaigns in } \\
\text { community development } \\
\text { and capacity-building }\end{array}$ & 16 & 18.8 \\
$\begin{array}{c}\text { Field visits to raise } \\
\text { agricultural productivity }\end{array}$ & 41 & 48.2 \\
\hline
\end{tabular}

Note. As resulted from the research

Table No. 2

Distribution of respondents according to the kind of practical courses attended

\begin{tabular}{ccc}
\hline $\begin{array}{c}\text { Courses that have been done for the } \\
\text { respondent by the development project }\end{array}$ & $\begin{array}{c}\text { Frequency } \\
(\mathbf{n = 8 5})\end{array}$ & Percentage \% \\
\hline Development training & 38 & 44.7 \\
Vocational training & 41 & 48.2 \\
\hline
\end{tabular}

Note. As resulted from the research

Table No. 3

Distribution of the respondents according to the duration of the project since initiation

\begin{tabular}{ccc}
\hline $\begin{array}{c}\text { Timeline since the start of the } \\
\text { project }\end{array}$ & $\begin{array}{c}\text { Frequency } \\
(\mathbf{n = 8 5 )}\end{array}$ & Percentage \% \\
\hline more than 4 years & 6 & 7.1 \\
3-4 years & 20 & 23.5 \\
Less than 3 years & 59 & 69.4 \\
\hline
\end{tabular}

Note. As resulted from the research 
Table No. 4

Distribution of respondents according to the type of productive project

\begin{tabular}{ccc}
\hline Project Type & Frequency $(\mathbf{n = 8 5})$ & Percentage $\%$ \\
\hline Irrigation projects & 5 & 5.9 \\
\hline Egg incubators & 3 & 3.5 \\
Mushroom production & 16 & 18.8 \\
Biogas & 43 & 50.6 \\
Solar cookers & 18 & 21.2 \\
\hline
\end{tabular}

Note. As resulted from the research

Table No. 5

Distribution of respondent according to the purpose of the project

\begin{tabular}{|ccc|}
\hline Purpose of the project & $\begin{array}{c}\text { Frequency } \\
(\mathbf{n = 8 5 )}\end{array}$ & Percentage \% \\
\hline Securing a new source of income & 19 & 22.4 \\
\hline $\begin{array}{c}\text { Expanding ideas about the } \\
\text { improvement of irrigation } \\
\text { systems }\end{array}$ & 5 & 5.9 \\
\hline $\begin{array}{c}\text { Providing an alternative source of } \\
\text { domestic gas }\end{array}$ & 61 & 71.8 \\
\hline
\end{tabular}

Note. As resulted from the research

Table No. 6

Distribution of respondents according to the economic and social impact of the project

\begin{tabular}{c|c|c|c|c}
\hline Response where $\mathbf{n = 8 5}$ & \multicolumn{2}{c|}{ NO } & \multicolumn{3}{c}{ YES } \\
\cline { 2 - 5 } & $\%$ & Frequency & $\%$ & Frequency \\
\hline The project generated a new source of income & 0 & 0 & 100 & 85 \\
electrical machines needed Purchasing & 100 & 85 & 0 & 0 \\
Saving money & 96.5 & 82 & 3.5 & 3 \\
\hline Improving the quality of food & 70.6 & 60 & 29.4 & 25 \\
\hline $\begin{array}{c}\text { Enrolling one or all the children to the school } \\
\text { Housing improvement }\end{array}$ & 100 & 85 & 0 & 0 \\
\hline
\end{tabular}

Note. As resulted from the research

Table No. 7

Distribution of respondents according to the existence of obstacles facing them

\begin{tabular}{ccc}
\hline $\begin{array}{c}\text { Obstacles which are } \\
\text { facing the target } \\
\text { respondent }\end{array}$ & $\mathbf{n}=\mathbf{8 5}$ & percentage\% \\
\hline Yes & 23 & 27.1 \\
No & 62 & 72.9 \\
\hline
\end{tabular}

Note. As resulted from the research 
Table No. 8

Distribution of respondents according to their suggested solutions to solve the problems that face them

\begin{tabular}{ccc}
\hline $\begin{array}{c}\text { Finding suggestions to } \\
\text { solve the problems that } \\
\text { face the respondent }\end{array}$ & $\mathbf{n = 8 5}$ & percentage\% \\
\hline Yes & 21 & 24.7 \\
No & 64 & 75.3 \\
\hline \multicolumn{2}{c}{ Note As resulted from the research } \\
\hline
\end{tabular}

Note. As resulted from the research

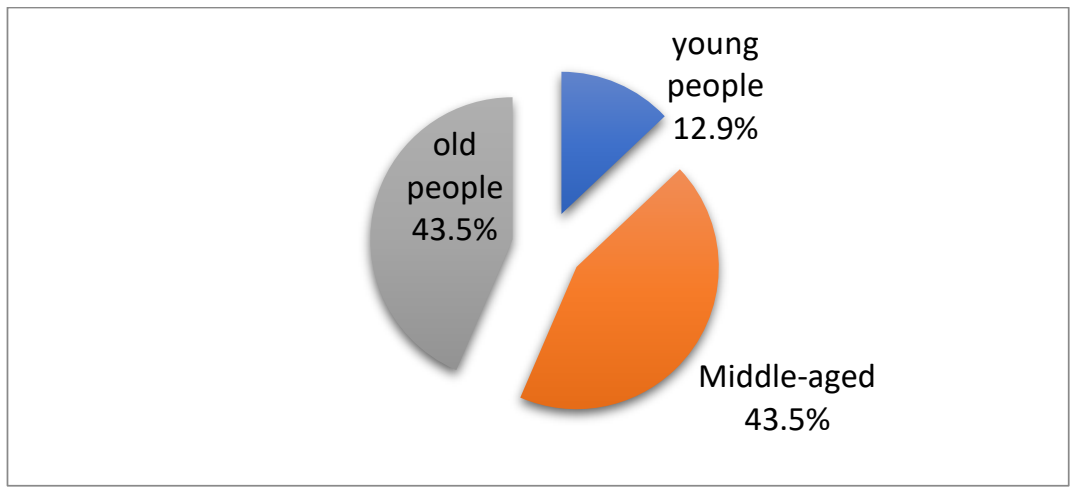

Figure No. 1

Distribution of the respondents according to the age Note. Own editing by SPSS

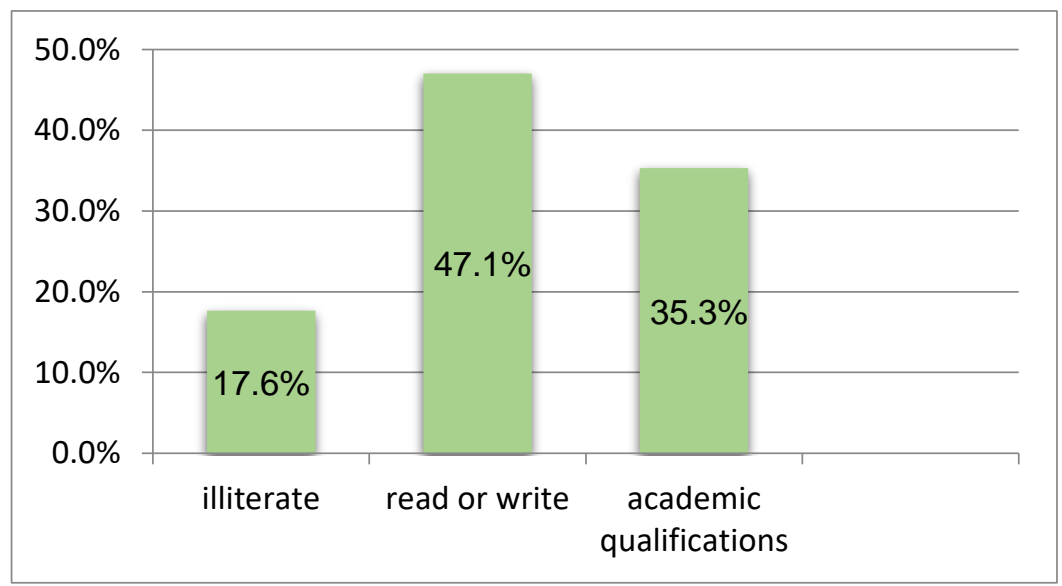

Figure No. 2

Distribution of the respondents according to educational level Note. Own editing by SPSS 


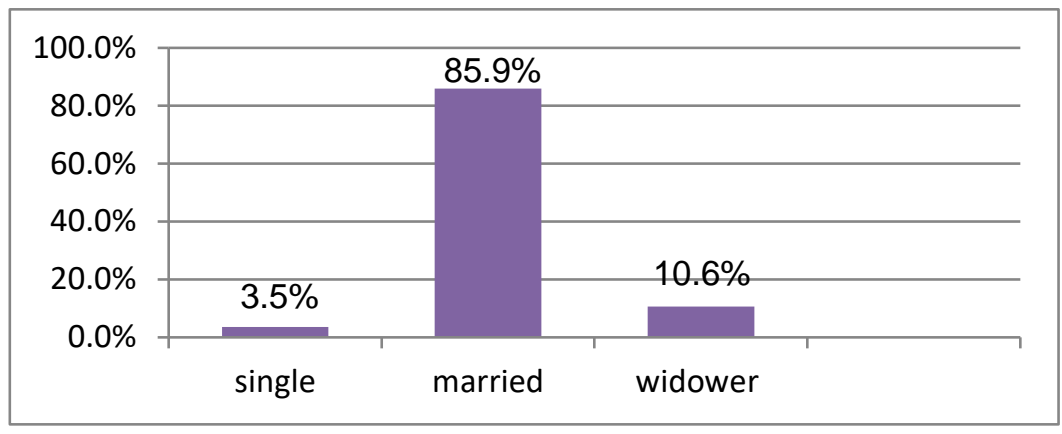

Figure No. 3

Distribution of the respondents according to marital status Note. Own editing by SPSS

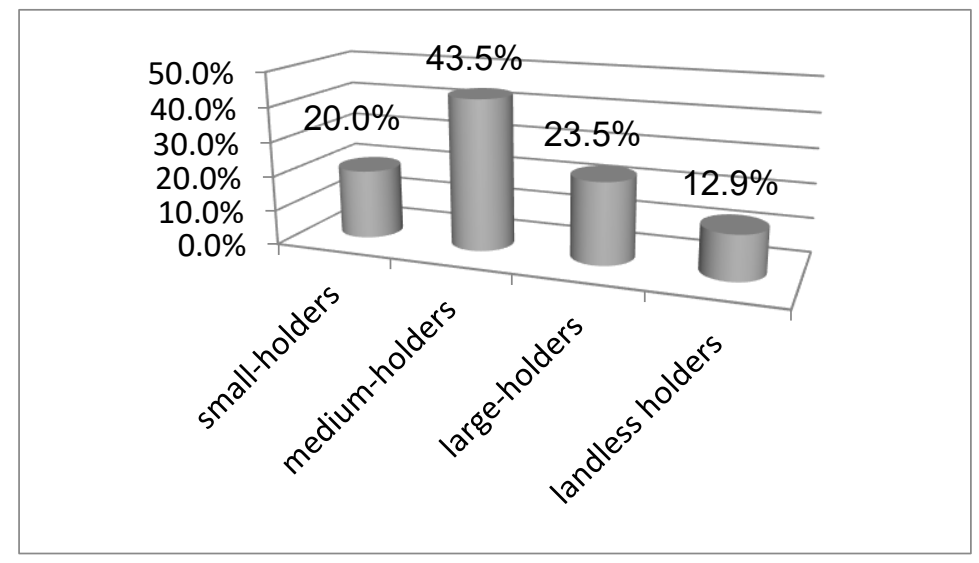

Figure No. 4

Distribution of the respondents according to size of tenure Note. Own editing by SPSS

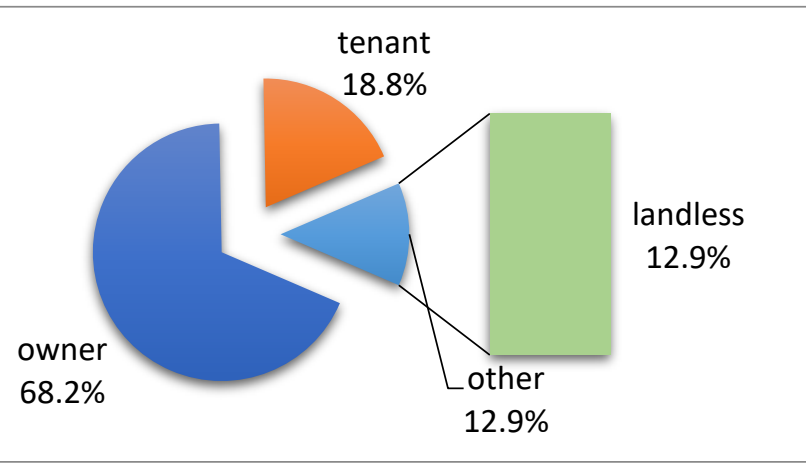

Figure No. 5

Distribution of the respondents According to the nature of tenure Note. Own editing by SPSS 


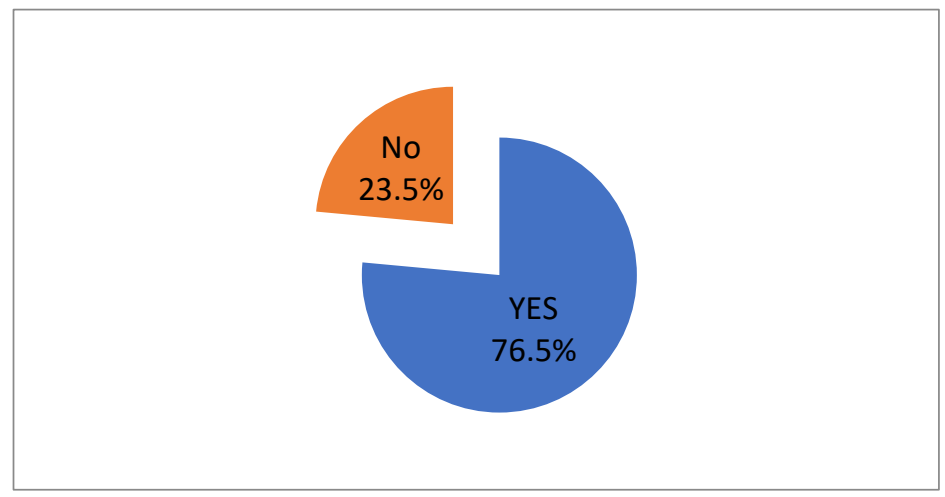

Figure No. 6

Distribution of respondents according to the continuity of the project Note. Own editing by SPSS

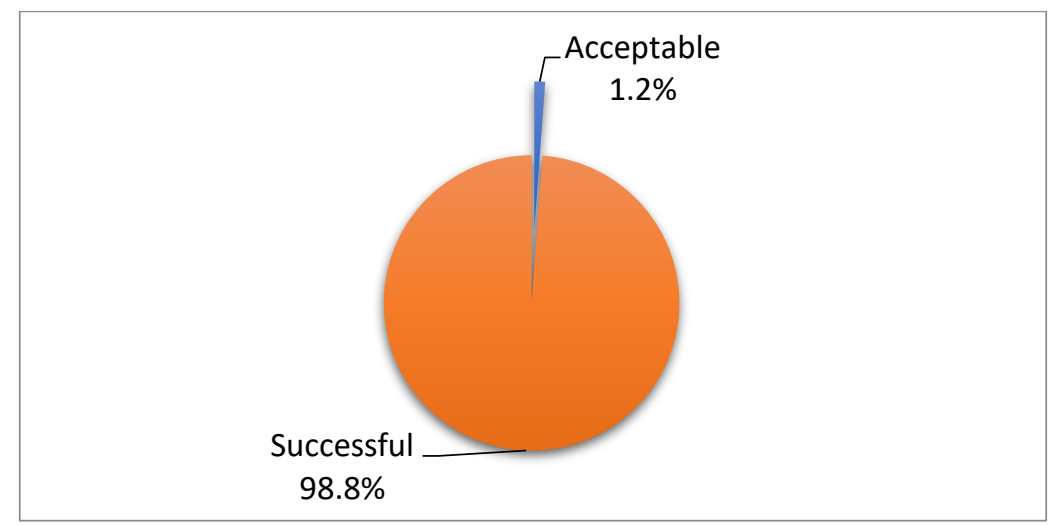

Figure No. 7

Distribution of respondents according to their evaluation of the project Note. Own editing by SPSS

\begin{tabular}{|c|}
\hline Difficulty in \\
securing raw \\
material for the \\
fermentative \\
(Biogas) \\
$13.0 \%$ \\
\\
\\
\\
\\
\\
\\
\\
\\
\\
vifficulty in \\
marketing \\
mushrooms \\
$78.3 \%$ \\
\hline
\end{tabular}

Figure No. 8

Distribution of respondents according to the problems facing them Note. Own editing by SPSS 


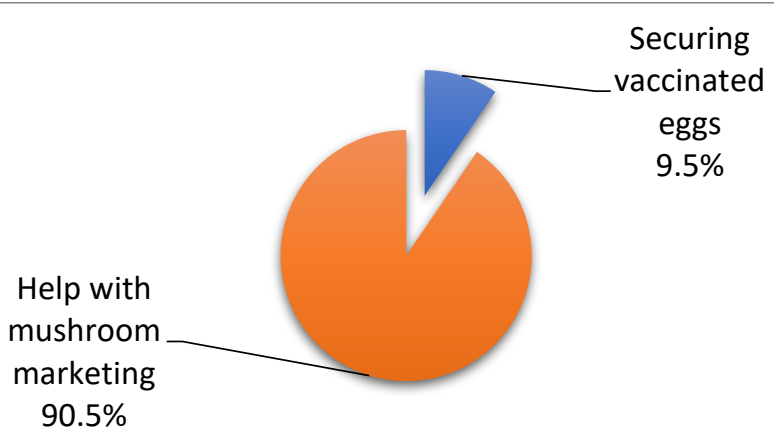

Figure No. 9

Distribution of respondents according to their propositions to solve the problems facing them Note. Own editing by SPSS 